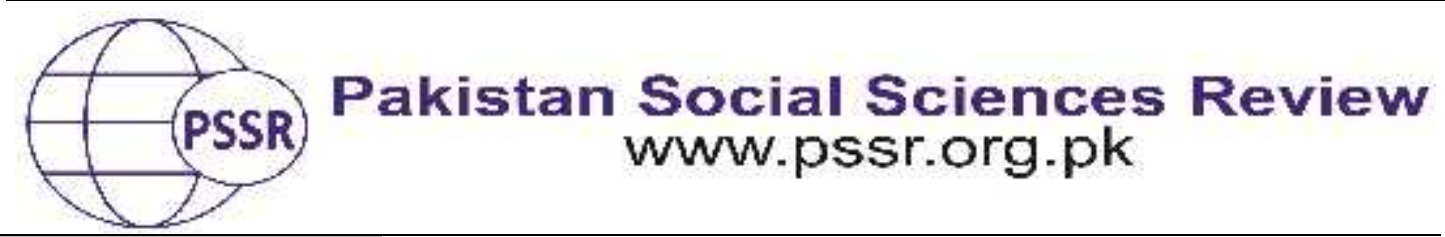

RESEARCH PAPER

\title{
Board Composition and Functioning, and Shareholders Rights to Information Impact on Earnings Management and Financial Performance: A Three Dimensional Analysis in Commercial Banking Sector of Pakistan
}

\author{
Muhammad Bilal ${ }^{1}$ Zafar Ahmad ${ }^{2}$
}

1. Ph. D Scholar, Hailey College of Commerce, University of the Punjab, Lahore, Punjab, Pakistan

2. Associate Professor, Hailey College of Commerce, University of the Punjab, Lahore , Punjab, Pakistan

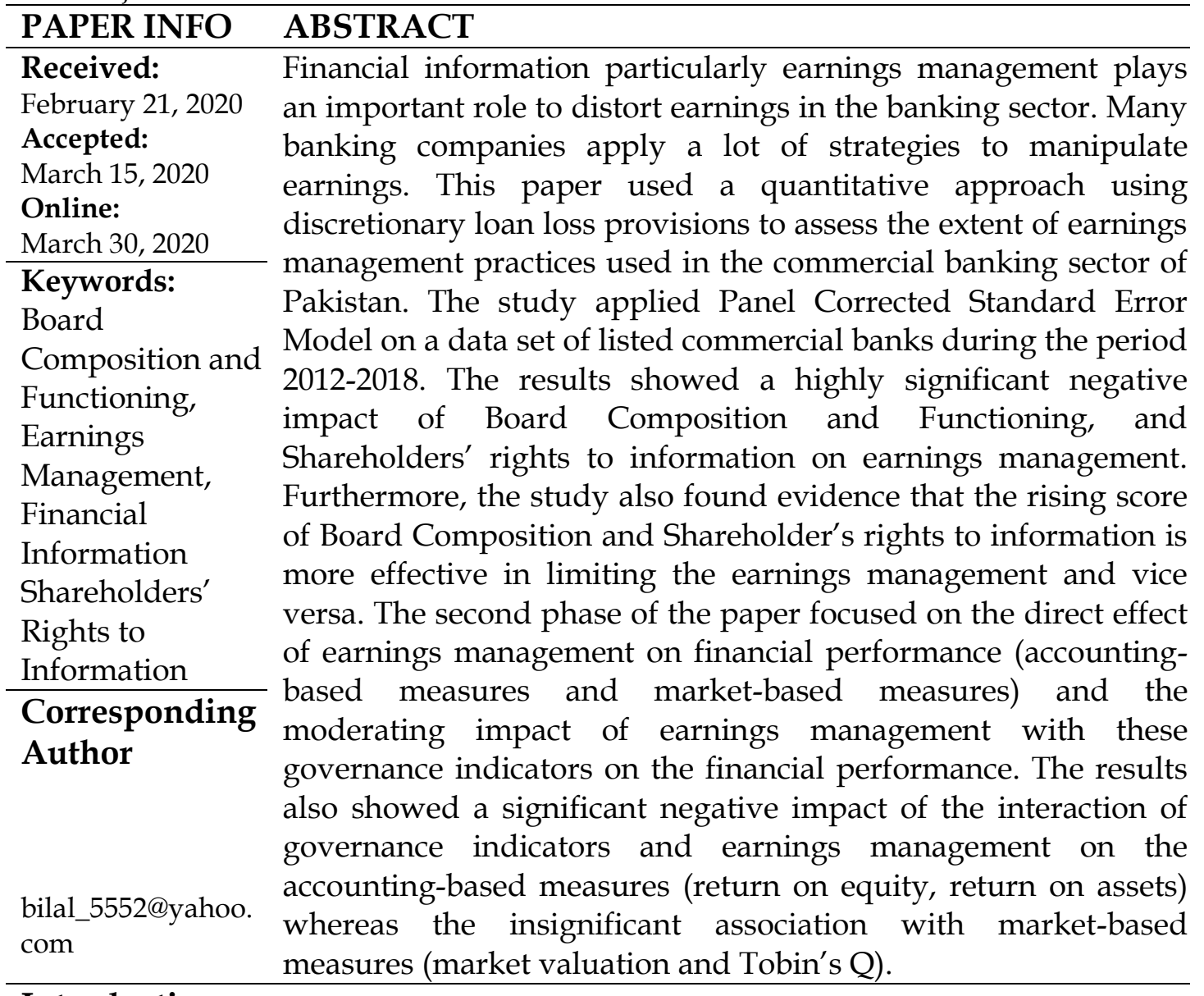

\section{Introduction}

The Commercial Banking sector is an important element in the financial system of any country, especially underdeveloped economies. How commercial 
bank performs tells a lot about the trust of all stakeholders. Corporate Governance mechanisms including both internal and external play a crucial role in the success of a commercial bank. Pakistan like other developing countries also relies much on its commercial banking sector for the development of its economy. Many other banks have developed mechanisms to supervise the practices adopted by the commercial banking sector for protection of stakeholders' rights and reduce agency costs. The developing countries banking industries especially Pakistan is also facing issues relating to internal and external governance.

In internal governance mechanisms, the board is considered an important mechanism for banking companies (Ahmed \& Ghazali, 2013; Khodadadi, Sohelia, \& Abbas, 2010). It is the apex of internal governance that controls top management, including the CEO. It hinges on the internal governance of a firm and plays a vital role in resolving agency conflict. The effectiveness of the board of directors depends on the board's characteristics.

Moreover, the heavy reliance on earnings by internal and external users creates an avenue for managers to use accounting discretion in arriving at earnings figures. The objective of this action is to meet earnings forecast and thresholds, analyst expectations, executive compensation, debt covenants, and capital finance and to influence regulatory decisions (Bernard \& Douglas, 1996; Healy \& Krishna, 2001; Roychowdhury, 2006). The reason for involvement in earnings management activities by managers is to avoid reputation damage and a strong negative share price reaction that may adversely damage the economy (Scott, 2015).

When there are large numbers of independent external directors on the board, there will be efficient monitoring of managers because the responsiveness of board independence is related to manager monitoring. Consequently, there will be a decrease in the costs of the agency as a result of the separation of ownership and control in the day-to-day management of the company (Brennan \& McDermott, 2004; Fama, 1980; Fama \& Jensen, 1983). Nevertheless, the findings of the existing literature with regards to board independence's relationship with real earnings management are mixed. In the research by Amran, Ishak, and Manaf (2016),board independence is found to be inversely linked to earnings management, which indicates the fact that board independence could curtail the real earnings management in the companies. Similarly, Kang and Kim (2012); Klein (2002); Uadiale (2012); Iraya et al. (2015) found that the more independent directors, the better the monitoring of the behavior of corporate managers. This position agrees with the agency theory perspective. Agency theory postulates that the independent directors' monitoring role is of importance. The primary aim of independent directors is to minimize the agency problem which emanates from the separation between management and ownership of the firm(Al-Rassas \& Kamardin, 2015; Benkel, Mather, \& Ramsay, 2006). In addition, independent directors should build a reputation as experts with experience and play a role in the identification and prevention of myopic behavior of corporate managers(Fama, 1980). However, the 
study by Hsu and Wen (2015)indicates board independence to be significantly and positively related to earnings management.

According to the Corporate Governance Codes, the chairman's duties and Chief Executive Officer's responsibilities should be dissimilar, as this will prevent excessive power of the CEO in managing daily business operations (ASE, 2009). This is congruent with the postulation of the agency theory. A CEO with excessive power on the board could, without difficulty, indulge in earnings management. Dualism like this in an office structure can facilitate effective information control, which could, in turn, hinder efficient monitoring(Ali, Ali, \& Mehmood, 2020; Jensen, 1993).

Although many studies were conducted to elaborate on the exact relationship between governance and earnings management practices but the discussion on the impact of internal governance mechanisms on earnings management remained unclear. A study conducted by Lawal, Nwanji, Opeyemi, and Adama (2018)explored the relationship between governance and earnings management on a data set of companies listed on the Nigerian Stock Exchange. The researchers ignored financial sector data on the basis of a unique feature of the annual financial reporting process of the industry. The study found that the relationship between the earnings management and internal governance is mixed at best. Specifically, it indicates that the Corporate Governance Code has a negative effect on earnings management, while the relationship between earnings management and insider ownership has been substantially positive. It was also noted that the independence of the Board and the Auditors had a minimal impact on the management of earnings. The study suggested strengthening the governance code of conduct for corporate and mandating compliance to restrict earnings management (Lawal et al., 2018).

The financial performance of the firms is also associated with the board. Yermack (1996)argues that value of the firm is negatively correlated with a large board. The size of the board may be influenced by quite a few variables; the optimum size of the board is hard to decide. They claim that whether it is smaller than the minimum legal requirement or is greater than two standard deviations from the mean, board size is considered excessive. On the other hand, Peasnell, Pope, and Young (2005); Vafeas (2000) suggested that a larger board could contribute to lower levels of income management because a higher number of independent and more experienced directors who are more capable of overseeing management activities are more likely to be included.

There is an extensive body of knowledge is available on individual factors of corporate governance. As such corporate directors' meeting is also considered as an integral part of the governance. Corporate board members who frequently meet may probably engage not in the management of earnings activities than board members with fewer meetings(Cornett, McNutt, \& Tehranian, 2009; Yao, Tang, Li, \& Jiang, 2015). In contrast, boards that meet less are likely to have less time to identify and resolve certain issues and can only focus their limited amount of time on management(Abed, Al-Attar, \& Suwaidan, 2012). 
However, the findings of the extant literature on the board meetings' relationship with earnings management are mixed. Some studies(Ahmed \& Ghazali, 2013; Xie, Davidson III, \& DaDalt, 2003)found that the management of earnings is negatively linked to the frequency of the board meetings. Specifically, Ahmed and Ghazali (2013)found that earnings management practices can be mitigated via frequent board meetings. However, Olayemi (2013) and Obigbemi, Omolehinwa, Mukoro, Ben-Caleb, and Olusanmi (2016)found a significant positive connection the board meeting has with earnings management practices, signifying that board meetings could influence managers engaging in real earnings management activities. In the study done by Obigbemi et al. (2016), it is signified that board activity can increase the management of earnings, and more frequent meetings of the board often help in the increment of the management of earnings. Also, they examined board meetings and earnings management relationships and the results signify a significantly positive relationship between board activity and earnings manipulation activities.

Board meetings' frequency in a year predicts how effective the board is and their monitoring responsibilities determine the level of vigilance and diligence on the part of the board(Persons, 2006). Moreover, agency theory assumes that frequent board meetings would strengthen corporate governance elements (Khanchel, 2007). In a firm where there are effectively-fixed and frequent board meetings, there would be economic growth. Also, the signaling theory suggests that the frequency of the board meeting is a signal of transparency in a company(Morris, 1987).It could be hypothesized, on the basis of the above discussion and postulations from both theories (agency and signaling), that regular meetings of active boards could increase efficiency in line with shareholder interests and control of the integrity of financial reporting.

The board has a significant role in containing the management activities of a company and protecting shareholder interests concerning internal governance structures (Fama \& Jensen, 1983). Corporate earnings are considered as a basic element by shareholders to determine whether to invest in the stock of a company(P. Dechow, Ge, \& Schrand, 2010; Shayan-Nia, Sinnadurai, Mohd-Sanusi, \& Hermawan, 2017). At the same time, earnings are the parameters on which the success of management is assessed and compensation is charged (Shayan-Nia et al., 2017). Managers may also very well have the incentives to inflate the reported earnings by using different accounting tactics and schemes to modify the timing and structure of investing, operating, and financing activities that would disappoint investors concerning the earnings power of the business. This exaggeration of financial results to confuse investors is referred to as earnings management (Beneish, 1997; Dechow, Sloan, \& Sweeney, 1995; Jones, 1991; Liao, Lin, \& Zhang, 2018).

Financial Information is the key to attract investment. The availability of information and shareholder's rights to that information also affect the financial performance of the firm. It can cause information asymmetry if the agent has more information than the principal but doesn't want to share information. According to 
(Stephen \& Scott, 2011)if one party has relevant information in a transaction but is unable (not willing) to share the information, it is called asymmetry information. Agency conflict occurs when information on asymmetry is available, whether it relates to any activity or agent information. Corporate governance requires a broad spectrum framework, is intended to address the risk of agency conflict by increasing the consistency of management activity reporting and limiting the opportunistic behavior of managers.

Prior studies have explored the effects of corporate board independence on governance effectiveness. Most of these studies illustrate the value of independent boards of directors, assisted by a higher percentage of independent non-executive directors, to control management activities. Fama and Jensen (1983)highlight the importance of independence from the corporate board to provide efficient monitoring of management activities and strategies. Williamson (1981)suggests that corporate board independence is required to protect the interests of shareholders. Roe (1991)supports the corporate board's monitoring position, on the ground that management practices cannot be restricted by legislative acts, and proposed that successful corporate board monitoring prevents managers from exploiting resources.

Some studies have explored the effect of board independence on earnings management empirically; these studies were mainly focused on data from developed countries such as the United Kingdom and the United States companies. The implications and causes of earnings management based on companies subject to compliance actions by the Securities and Exchange Commission (SEC) were assessed by Dechow et al. (1995). Their results show that "the risk of earnings manipulations is systematically connected to deficiencies in management control,' and they conclude that businesses with greater manipulation of earnings are more likely to have a board dominated by insiders. In another study, Beasley (1996)proposed that the presence of a greater proportion of external directors on boards decreases the risk of fraud in financial statements.

Academics and professionals believe that a major determinant of company performance is board size. Large-sized boards hinder coordination and decisionmaking problems and severely damage the quality of monitoring. Jensen (1993) asserts that "when boards get beyond seven or eight people they are less likely to function effectively". Lipton and Lorsch (1992)suggest restricting the number of directors, with an ideal of eight or nine members, to a maximum of ten members. Yermack (1996)supports the idea that smaller boards are more productive, thus leading to an opposite relation between board size and financial performance. The study also concluded that firm value is hindered by a large board. The size of the board may be influenced by quite a few variables; the optimum size of the board of directors is hard to decide. We claim that whether it is smaller than the minimum legal requirement or is greater than two standard deviations from the mean, board size is considered excessive. 
A large board size may contribute to lower-quality financial reporting since a higher number of independent and more qualified directors who would be more able to track management activities are more likely to be included (Peasnell et al., 2005; Vafeas, 2000).

\section{Material and Methods}

\section{Data and Empirical Model}

Various studies are available that highlight the differences of numerous approaches in scoring governance indicators along with their pros and cons. Experts are reluctant to agree over whether or not a particular dimension of governance indicators should be used, and also how much importance each factor will be provided (Ali, Ali, Khan, \& Ghulam, 2020; Shamsi, Bashir, \& Panhwar, 2013). This paper used a quantitative methodology. In the first phase earnings management practices were discovered using a regression equation to find residuals (discretionary loan loss provisions) in banking companies as suggested by Stubben (2010). In the second phase, two indices were constructed for board composition and functioning (Factors included: the percentage of independent directors, nonexecutive directors, Chief Executive Officer and Chairman separation, attendance and regularity of meetings) and shareholder's rights to information (Factors included: information about all shareholdings, proxy voting criteria, complaint redressal systems, and dividend declaration and distribution criteria) separately. After the formulation of indices, multiple regression equations were used to analyze the relationship of earnings management with that of board composition and functioning index and shareholder's rights to information Index. In the last phase, the impact of both governance indicators on the financial performance directly and using earnings management as a moderating variable of banking companies were measured. The model used in this study is as follows.

$$
\begin{aligned}
& L L P \quad=\beta_{0}+\beta_{1} C O+\beta_{2} B B A L+e_{1} \\
& E M / D L L P=\beta_{0}+\beta_{1} B C F I+\beta_{2} S R I I+e_{2} \\
& F P \quad=\beta_{0}+\beta_{1} B C F I+\beta_{2} S R I I+\beta_{3} B C F I^{*} E M+\beta_{4} S R I I^{*} E M+e_{3}
\end{aligned}
$$

Whereas financial performance is measured by both accounting-based (Return on Assets, Return on Equity) and market-based (Market Capitalization, and Tobin's Q) measures

FP = Financial Performance

LLP =Loan Loss Provision; $\mathrm{CO}=$ Loan Charge offs

$\mathrm{BBAL}=$ Beginning Balance for allowance for bad debts

EM/DLLP = Earnings Management or Discretionary Loan Loss Provisions 
BCFI =Board Composition and Functioning Index;

SRII = Shareholder's Rights to Information Index

ROA $=$ Return on Assets $=$ Net income divided by total assets

$\mathrm{ROE}=$ Return on Equity $=$ Net income divided by total equity

$\mathrm{MV}=$ Market valuation $=$ Outstanding shares of a company $\mathrm{x}$ current share price

Tobin's $\mathrm{Q}=\mathrm{Q}$ Ratio = Market value of assets $/$ replacement cost of the company's assets

The Hypotheses that were developed to evaluate the relationship expressed in the econometric model are as follows.

\section{Hypotheses}

\section{Theoretical Base Relationship \\ By Literature (Expected)}

Internal Governance Mechanisms and H1 Earnings Management Board composition and functioning Shareholder's Rights to Information
Agency Theory ; Negative Public Interest

H1a Theory

$\mathrm{H} 1 \mathrm{~b}$

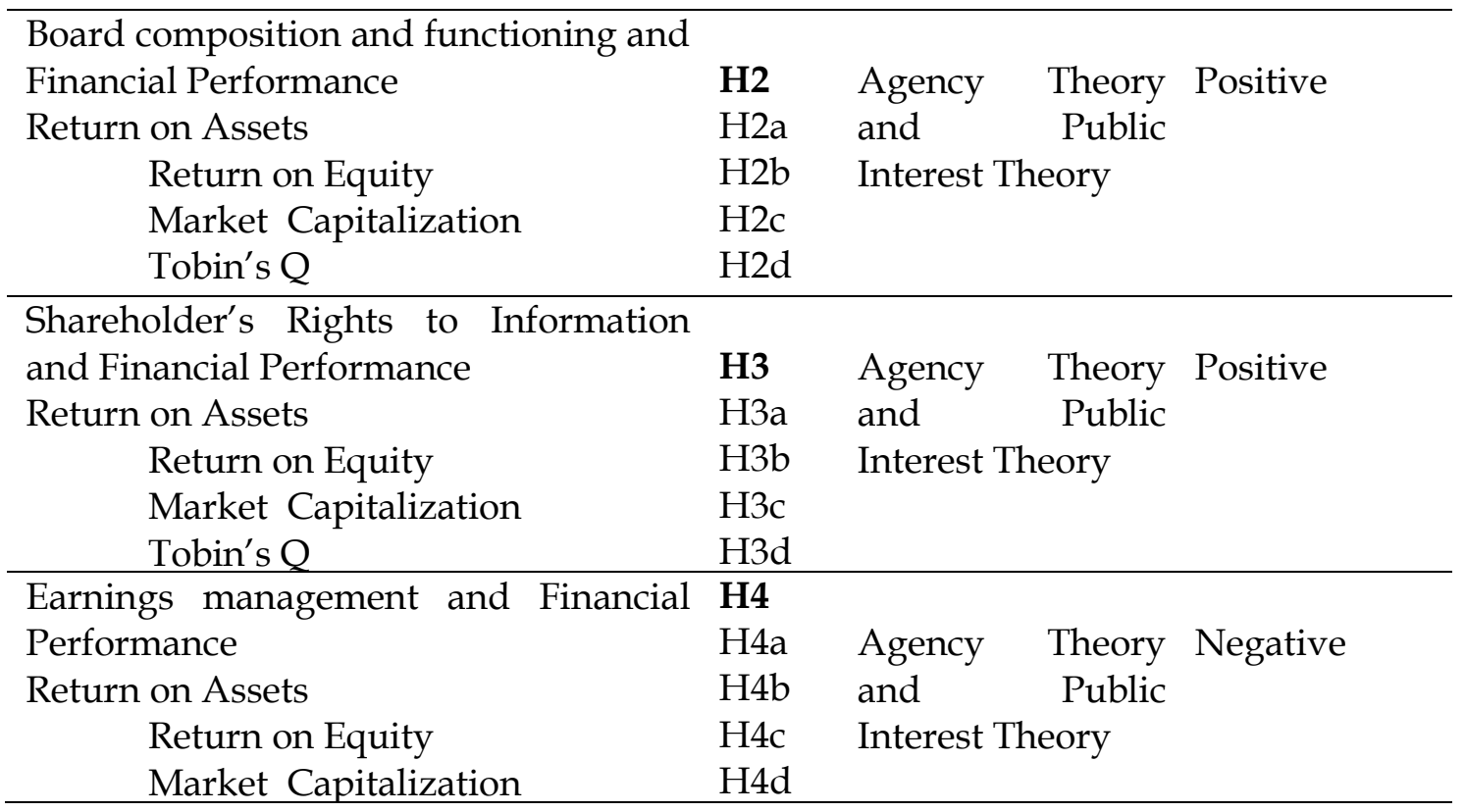


Board composition and functioning on financial performance using earnings management as moderating variable

Return on Assets

Return on Equity

H5

Agency Theory Negative

Market Capitalization and Public

Tobin's Q

H5a Interest Theory

$\mathrm{H} 5 \mathrm{~b}$

$\mathrm{H} 5 \mathrm{c}$

$\mathrm{H} 5 \mathrm{~d}$

Shareholder's Rights to Information on

financial performance using earnings management as moderating variable

Return on Assets

H6 and $\quad$ Public Negative

H6a

Interest Theory

$\begin{array}{ll}\text { Return on Equity } & \mathrm{H} 6 \mathrm{~b} \\ \text { Market Capitalization } & \mathrm{H} 6 \mathrm{c} \\ \text { Tobin's } & \mathrm{H} 6 \mathrm{~d}\end{array}$

\section{Results and Discussion}

\section{Tests for Normality and Stationarity of Data}

Test for normality of quantitative data was conducted through SPSS, whereas Skewness and Kurtosis through Stata. According to the previous studies(Bulmer, 1979) the data range for Skewness is +1 to -1 whereas for kurtosis as per Balanda and MacGillivray (1988) the range is 3 to -3 . So all the dependent and independent variables fulfilled the assumption of normality and data also fulfilled the normality for Skewness and Kurtosis. The values for skewness, kurtosis, and variance are mentioned in Table 2.

Table 2

Summary Statistics for Panel Data Sample for Banking Companies

\begin{tabular}{cccc}
\hline Variables & Skewness & Kurtosis & Variance \\
\hline $\begin{array}{c}\text { Board Composition and } \\
\text { Functioning Index }\end{array}$ & -.580491 & 2.03998 & 2.893275 \\
\hline $\begin{array}{c}\text { Shareholder' Right Index } \\
\text { Earnings Management } \\
\text { (DLLP) }\end{array}$ & .249842 & 2.693699 & 2.335813 \\
\hline Return on Assets (ROA) & -.5660006 & 1.277792 & 1.18098 \\
\hline Return on Equity (ROE) & -.5125709 & 2.876017 & .6821523 \\
\hline Market Capitalization & -.786923 & 2.33485 & 7.5287 \\
\hline Tobin's Q & .0822506 & 1.947958 & 1.704983 \\
\hline & 0.963352 & 2.803455 & 8.75356 \\
\hline
\end{tabular}


Table 3

Unit root test for corporate governance and financial performance variables

Levin linchu test was used to check the stationarity of the data. All the variables fulfilled the stationarity test and there were no unit root exists in the data.

\begin{tabular}{|c|c|c|c|c|}
\hline Levin-Lin-Chu Test & & Panel 1 & ans: Inc & \\
\hline ADF Regression & 1 Lag & Time $t$ & end: Included & \\
\hline Variables & $\begin{array}{l}\text { Value } \\
\text { Adjusted T* }\end{array}$ & $\begin{array}{l}\mathrm{P}- \\
\text { value }\end{array}$ & Unit root & $\begin{array}{l}\text { Panel } \\
\text { Status }\end{array}$ \\
\hline $\begin{array}{l}\text { Board Composition and } \\
\text { Functioning Index }\end{array}$ & $-242279 *$ & 0.0000 & No Unit Root & Stationary \\
\hline $\begin{array}{l}\text { Shareholder' Rights to } \\
\text { InformationIndex }\end{array}$ & -22 & 0.0000 & $\mathrm{NoIr}$ & ry \\
\hline Management & $-25.3927^{*}$ & 0.0000 & No Unit Root & Sta \\
\hline Return on Assets (ROA) & -55.53 & 0.0000 & No Unit Root & St \\
\hline Return on Equity (ROE) & $-12.4996^{*}$ & 0.0000 & No Unit Root & Stationary \\
\hline Market Capitalization & $-1.20 \mathrm{E}+02^{*}$ & 0.0000 & No Unit Root & Stationary \\
\hline Tobin's Q & $-40.293^{*}$ & 0.0000 & No Unit Root & Stationary \\
\hline
\end{tabular}

The summary is as follows.

Table 4

Correlation of Earnings Management, Governance Indices and Financial

Performance Variables

\begin{tabular}{|c|c|c|c|c|c|c|c|}
\hline $\begin{array}{l}\text { Independent } \\
\text { Variables }\end{array}$ & BCI & SRII & ROA & ROE & MV & $\begin{array}{l}\text { Tobins' } \\
Q\end{array}$ & EM \\
\hline $\mathrm{BCI}$ & 1 & & & & & & \\
\hline SRII & 0.042 & 1 & & & & & \\
\hline P-Value & .621 & & & & & & \\
\hline $\mathrm{ROA}$ & $0.153^{*}$ & $0.262^{* *}$ & 1 & & & & \\
\hline P-Value & .070 & .002 & & & & & \\
\hline ROE & $0.224^{* * *}$ & $0.271^{\text {** }}$ & $0.808^{* * *}$ & 1 & & & \\
\hline P-Value & .008 & .001 & .000 & & & & \\
\hline MV & 0.081 & $0.1742^{* *}$ & $0.583^{* * *}$ & $0.353^{* * *}$ & 1 & & \\
\hline P-Value & .338 & .040 & .000 & .000 & & & \\
\hline Tobins' Q & $0.141^{*}$ & $0.222^{* *}$ & $0.730^{* * *}$ & $0.362^{* *}$ & $0.737^{* * *}$ & 1 & \\
\hline P-Value & .0 .09 & .008 & .000 & .006 & .000 & & \\
\hline EM & $-0.147^{*}$ & $-0.080^{*}$ & $0.204^{\star * *}$ & $0.121^{* *}$ & $0.311^{* * *}$ & $0.169^{* *}$ & 1 \\
\hline P-Value & .097 & .088 & .000 & .006 & .000 & .046 & \\
\hline
\end{tabular}

Table 4 showed that the Board Composition and Functioning Index has a strong positive correlation with accounting-based measures of financial performance, including return on assets, return on equity whereas no significant correlation with market-based performance measures such as market capitalization. 
Moreover, the Board Index also exhibits a significant negative correlation with Discretionary loan loss provisions (DLLP). However, Shareholder's rights to information index showed a strong positive correlation with return on assets, return on equity, Tobins' $Q$, and market valuation whereas a strong significant negative association was found with earnings management (DLLP). Earnings Management (DLLP) was also significantly positively correlated with all financial performance indicators.

Table 5

Simple and multiple linear Regression Results of Beta Coefficients of the Board and Rights Indices on Earnings Management (DLLP) by Panel Corrected Standard Error Model for Heteroskedasticity and Auto corelated data Earnings Management (DLLP)

\begin{tabular}{llll}
\hline Independent Variables & I & II & III \\
\hline Board Composition and Functioning Index & $-0.090^{* * *}$ & & $-0.086^{* *}$ \\
\hline P-value & 0.001 & & 0.002 \\
\hline Shareholder' Rights to Information Index & & $-0.102^{* * *}$ & $-0.098^{* *}$ \\
\hline P-value & & 0.009 & 0.012 \\
\hline R-Squared & 0.199 & 0.210 & 0.0312 \\
\hline Wald chi2(1) & 10.97 & 6.91 & 14.05 \\
\hline Prob> chi2 & 0.000 & 0.008 & 0.000 \\
\hline Serial Correlation F-Test Value & $21.272^{* * *}$ & $21.920^{* * *}$ & $21.896^{* * *}$ \\
\hline Prob> F & 0.000 & 0.000 & 0.000 \\
\hline (Wooldridge test for autocorrelation in panel data & $\begin{array}{l}\text { Note.: } \\
\text { value }<0.05,{ }^{* *} \mathrm{p} \text {-value }<\text {-value }<0.10\end{array}$ \\
\hline H0: no first order autocorrelation) & & \\
\hline
\end{tabular}

I. This regression equation showed that the Board Composition and Functioning Index have highly significant negative relationship with that of Earnings Management (DLLP). It means as the governance score of Board increases the DLLP is decreasing with the value of 0.0900 . Woolridge test for autocorrelation showed the presence of serial correlation so adjustment was made in performing analysis using Panel Corrected Standard Error Model. Rsquared value of 0.199 shows the explanatory power of the board characteristics in determining Earnings Management (DLLP).

II. This regression equation showed that the Shareholder's Rights to Information Index have highly significant negative relationship with that of Earnings Management (DLLP). It means as the governance score of Rights to Information increases the DLLP is decreasing with the value of 0.1029 with Rsquared of 21 percent.

III. This regression equation analyzed the joint impact of Board Composition and Functioning Index and Shareholder's Rights to Information Index. Both the 
indices have highly significant negative relationship with that of Earnings Management (DLLP). It means as the governance score of Board and Rights to Information increases the DLLP is decreasing with the value of 0.0863 and 0.0989 with R-squared of 0.312 .

Table 6

Multiple Regression Results of Beta Coefficients of ROA using the Board Index and Shareholder's Rights to information Index and Earnings Management as Independent Variable by Panel Corrected Standard Error Model for Heteroskedasticity and Autocorelated data

Return on Assets (ROA)

\begin{tabular}{|c|c|c|c|c|c|}
\hline Independent Variables & $\mathbf{I}$ & II & III & IV & $\mathbf{V}$ \\
\hline $\begin{array}{l}\text { Board Composition and } \\
\text { Functioning Index }\end{array}$ & $.07470^{* * *}$ & & & $.0952^{* *}$ & \\
\hline P-value & 0.000 & & & 0.000 & \\
\hline Shareholder' Right Index & & $.141^{* * *}$ & & $0.127^{* *}$ & \\
\hline P-value & & 0.000 & & 0.000 & \\
\hline Earnings Management & & & $.2436^{* * *}$ & $.1680^{* * *}$ & \\
\hline P-value & & & 0.000 & 0.000 & \\
\hline $\begin{array}{l}\text { Board Composition and } \\
\text { Earnings Management } \\
\text { (DLLP) Moderation }\end{array}$ & & & & & $-0.257^{*}$ \\
\hline P-value & & & & & 0.067 \\
\hline $\begin{array}{l}\text { Shareholder' Right and } \\
\text { Earnings Management } \\
\text { (DLLP)Moderation }\end{array}$ & & & & & $0.207^{*}$ \\
\hline P-value & & & & & 0.052 \\
\hline R-Squared & 0.123 & 0.068 & 0.102 & 0.237 & 0.05 \\
\hline Wald chi2(2) & 14.60 & 13.81 & 50.26 & 43.83 & 10.92 \\
\hline Prob> chi2 & 0.0001 & 0.0002 & 0.0000 & 0.0000 & 0.003 \\
\hline $\begin{array}{l}\text { Serial Correlation F-Test } \\
\text { value }\end{array}$ & 1.492 & 1.354 & 1.507 & 1.605 & 1.454 \\
\hline P-value & 0.236 & 0.258 & 0.234 & 0.220 & 0.242 \\
\hline \multicolumn{2}{|c|}{$\begin{array}{l}\text { Wooldridge test for autocorrelation in } \\
\text { panel data }\end{array}$} & \multicolumn{4}{|c|}{$\begin{array}{l}\text { Note.: }{ }^{* * *} \mathrm{p} \text {-value }<0.001,{ }^{* *} \mathrm{p} \text {-value }<0.05,{ }^{*} \mathrm{p}- \\
\text { value }<0.10\end{array}$} \\
\hline $\begin{array}{l}\text { H0: no first order } \\
\text { autocorrelation }\end{array}$ & & & & & \\
\hline
\end{tabular}

I. This equation showed the impact of the Board Characteristics on the return on assets (ROA). The coefficient was highly positive significant with an R-squared of 0.1237 . This means as the score of the board improved the return on assets also increased by 0.7470 . 
II. Shareholder's Rights to Information Index showed a strong positive relationship with the return on assets which is significant at a $1 \%$ level of significance.

III. Earnings management showed a positive significant relationship with the return on assets having an r-squared of 0.1028 and the model was also fit. It means a high level of earnings management also leads to a high return on assets which is contradictory to the facts.

IV. This equation evaluated both indices and earnings management. The results showed a highly significant positive association of all with return on assets.

V. This equation analysed the moderating impact of governance indicators and earnings management on the return on assets. In this the board characteristics showed a significant negative moderating impact on return on assets which was previously positive when measured directly using earnings management (DLLP). Whereas the shareholder's rights to information showed a positive moderating impact.

Table 7

Multiple Regression Results of Beta Coefficients of ROEusing the Board Index and Shareholder's Rights to information Index and Earnings Management as Independent Variable by Panel Corrected Standard Error Model for Heteroskedasticity and Autocorelated data

Return on Equity (ROE)

\begin{tabular}{|c|c|c|c|c|c|}
\hline Independent Variables & $\mathbf{I}$ & II & III & IV & $\mathbf{V}$ \\
\hline $\begin{array}{l}\text { Board Composition and } \\
\text { Functioning Index }\end{array}$ & $0.059^{*}$ & & & $0.073^{* *}$ & \\
\hline P-value & 0.073 & & & 0.027 & \\
\hline Shareholder' Right Index & & $0.108^{* *}$ & & $0.127^{* *}$ & \\
\hline P-value & & 0.034 & & 0.019 & \\
\hline Earnings Management & & & $0.215^{* * *}$ & $0.252^{* * *}$ & \\
\hline P-value & & & 0.000 & 0.000 & \\
\hline $\begin{array}{l}\text { Board Composition and } \\
\text { Earnings Management } \\
\text { (DLLP) Moderation }\end{array}$ & & & & & $-0.066^{*}$ \\
\hline P-value & & & & & 0.063 \\
\hline $\begin{array}{l}\text { Shareholder' Right and } \\
\text { Earnings Management } \\
\text { (DLLP)Moderation }\end{array}$ & & & & & $0.0401^{*}$ \\
\hline P-value & & & & & 0.0952 \\
\hline R-Squared & 0.169 & 0.110 & 0.100 & 0.195 & 0.217 \\
\hline Wald chi2(2) & 3.22 & 4.49 & 16.80 & 14.39 & 15.93 \\
\hline
\end{tabular}




\begin{tabular}{|c|c|c|c|c|c|}
\hline Prob> chi2 & 0.072 & 0.034 & 0.000 & 0.002 & 0.003 \\
\hline $\begin{array}{l}\text { Serial Correlation F-Test } \\
\text { value }\end{array}$ & 2.204 & 2.095 & 2.274 & 1.413 & 2.319 \\
\hline P-value & 0.154 & 0.164 & 0.148 & 0.249 & 0.144 \\
\hline $\begin{array}{l}\text { Wooldridge test for autocor } \\
\text { panel data }\end{array}$ & rrelation in & $\begin{array}{l}\text { Note.: } \\
\text { value }\end{array}$ & o-valu & $01,{ }^{* *} \mathrm{p}$ & $e<0.05$ \\
\hline
\end{tabular}

I. This equation showed the effect of Board Characteristics on the return on equity (ROE). The coefficient was significantly positive with an r-squared value of 0.1693 . This means as the score of the board improved the return on equity also increased by 0.0594 .

II. Shareholder's Rights to Information Index showed a strong positive relationship with the return on equity, which is significant at a $1 \%$ level of significance.

III. Earnings management also showed a positive significant relationship with the return on equity when observed in an independent equation having an r-squared of 0.1005 and the model was also fit. It means a high level of earnings management also leads to a high return on equity which showed adopted practices of earnings management manipulate earnings in a positive direction to influence decision making.

IV. This equation evaluated both indices and earnings management. The results exhibited a highly significant positive association of all with the return on equity having r-squared of 0.1952 .

V. This equation analysed the moderating impact of governance indicators and earnings management on the return on equity. In this, the board characteristics showed a significant negative moderating impact on return on equity which was previously positive when directly using earnings management (DLLP) measured. Whereas the shareholder's rights to information showed a positive significant moderating impact on the return on equity.

Table 8

Multiple Regression Results of Beta Coefficients of Market Capitalizationusing the Board Index and Shareholder's Rights to information Index and Earnings Management as Independent Variable by Panel Corrected Standard Error Model for Heteroskedasticity and Autocorelated data

\begin{tabular}{l|lllll} 
& \multicolumn{9}{c}{$\begin{array}{l}\text { Market } \\
\text { Capitalization }\end{array}$} & \\
\hline Independent Variables & I & II & III & IV & V \\
\hline
\end{tabular}




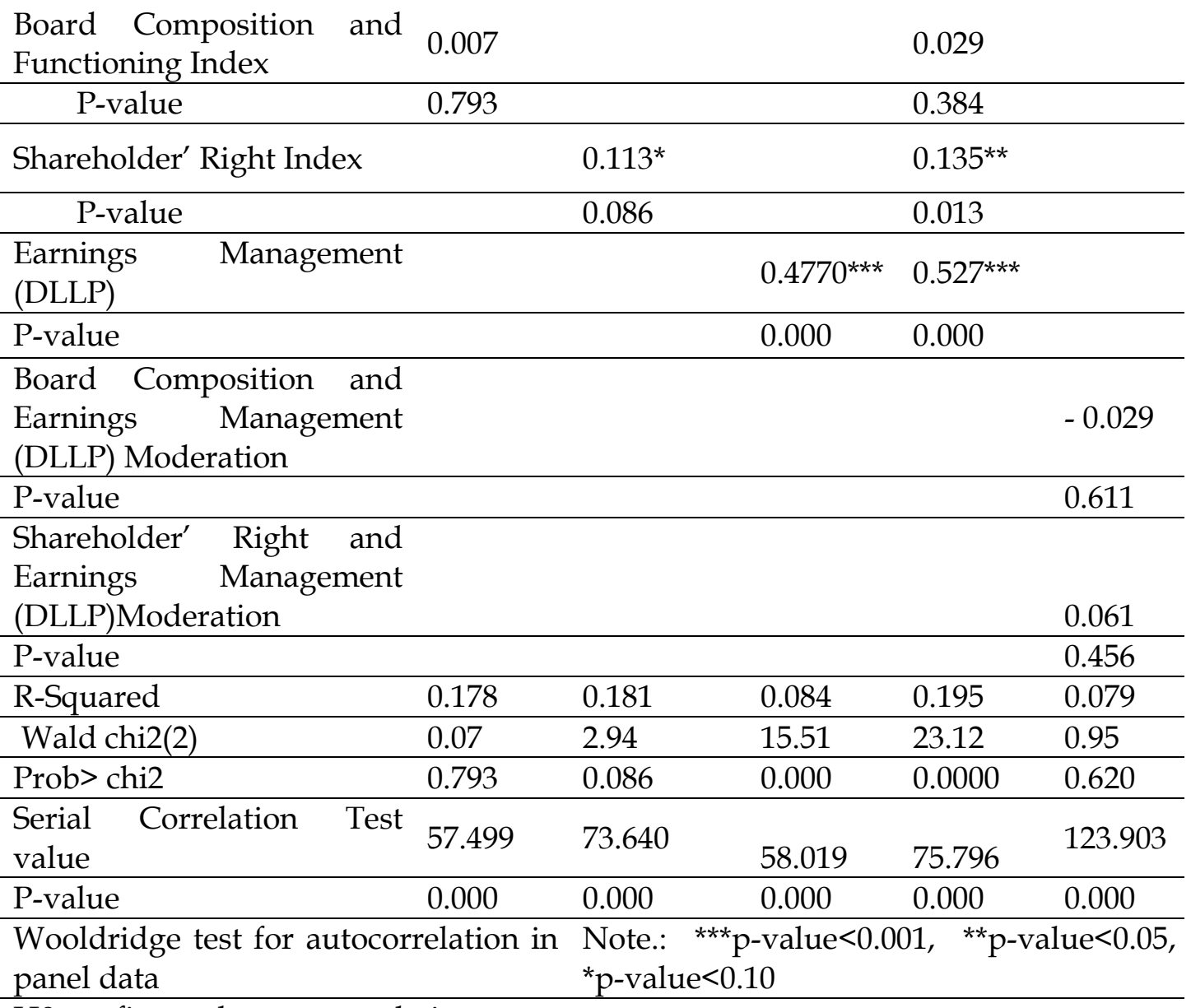

$\mathrm{H} 0$ : no first order autocorrelation

I. The coefficient of the board was insignificant with market capitalization. This means the board characteristics does not have any significant effect on the market valuation of the stocks of banking companies.

II. Shareholder's Rights to Information Index showed a strong positive relationship with the market capitalizationhaving an r-squared of 0.1816 anda coefficient value of 0.1173 which is significant at a $1 \%$ level of significance.

III. Earnings management showed a positive significant relationship with market capitalization having an r-squared of 0.0844 and the model was also fit at a $1 \%$ level of significance. It means a high level of earnings management practices also leads to themanipulativehigh value of the stock.

IV. This equation evaluated both indices and earnings management. The results showed a highly significant positive association of all with market capitalization. 
V. This equation analysed the moderating impact of earnings management and both the governance indicators and on the market capitalization. Both showed an insignificant moderating impact on market capitalization.

Table 9

Multiple Regression Results of Beta Coefficients of Tobin's Q using the Board Index and Shareholder's Rights to information Index and Earnings Management as Independent Variable by Panel Corrected Standard Error Model for Heteroskedasticity and Autocorelated data

\begin{tabular}{|c|c|c|c|c|c|}
\hline \multicolumn{6}{|c|}{ Tobin's Q } \\
\hline Independent Variables & I & II & III & IV & $\mathbf{V}$ \\
\hline $\begin{array}{l}\text { Board Composition and } \\
\text { Functioning Index }\end{array}$ & 0.196 & & & 0.217 & \\
\hline P-value & 0.331 & & & 0.317 & \\
\hline Shareholder' Right Index & & 0.212 & & 0.314 & \\
\hline P-value & & 0.640 & & 0.478 & \\
\hline Earnings Management & & & 0.8791 & 0.941 & \\
\hline$P$-value & & & 0.195 & 0.190 & \\
\hline $\begin{array}{l}\text { Board Composition and } \\
\text { Earnings Management } \\
\text { (DLLP) Moderation }\end{array}$ & & & & & 0.412 \\
\hline P-value & & & & & 0.188 \\
\hline 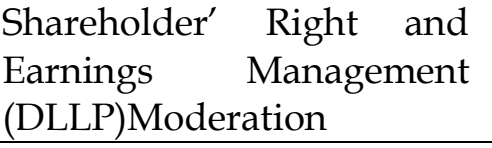 & & & & & 0.620 \\
\hline P-value & & & & & 0.182 \\
\hline R-Squared & 0.128 & 0.132 & 0.138 & 0.149 & 0.165 \\
\hline Wald chi2(2) & 0.95 & 0.22 & 1.68 & 1.89 & 4.34 \\
\hline Prob> chi2 & 0.330 & 0.640 & 0.195 & 0.594 & 0.502 \\
\hline $\begin{array}{lll}\text { Serial Correlation } \mathrm{F} \text {-Test } \\
\text { value }\end{array}$ & 15.328 & 14.703 & 16.009 & 15.275 & 14.499 \\
\hline P-value & 0.000 & 0.001 & 0.000 & 0.000 & 0.001 \\
\hline $\begin{array}{l}\text { Wooldridge test for autocor } \\
\text { panel data }\end{array}$ & relation in & $\begin{array}{l}\text { Note.: }{ }^{* * *} 1 \\
\text { value }<0.1 \\
\end{array}$ & alue $<0.0$ & $1,{ }^{* *} \mathrm{p}-$ & $<0.05,{ }^{*} \mathrm{p}$ \\
\hline
\end{tabular}

H0: no first order autocorrelation

I. This equation showed the impact of Board Characteristics on Tobin's Q. The coefficient was insignificant, depictinginsignificant relationship of Board characteristics and market-based performance measures.

II. Shareholder's Rights to Information Index also showed an insignificant impact on market capitalization, even at a $10 \%$ level of significance. 
III. Earnings management showed an insignificant relationship with Tobin's Q.

IV. This equation evaluated both indices and earnings management. The results showed an insignificant relation of all variables with Tobin's $Q$.

V. This equation analysed the moderating impact of governance indicators and earnings management on Tobin's Q. The results were also insignificant.

Table 10

Summarized Hypotheses Results

Dependent Variables

\begin{tabular}{|c|c|c|c|c|c|}
\hline $\begin{array}{l}\text { Independent } \\
\text { Variables }\end{array}$ & EM & ROA & ROE & MV & Tobin's Q \\
\hline & $\begin{array}{c}\mathrm{H}_{\mathrm{a}} \\
\text { (Accepted) }\end{array}$ & $\begin{array}{c}\mathrm{H} 2_{\mathrm{a}} \\
\text { (Accepted) }\end{array}$ & $\begin{array}{c}\mathrm{H} 2_{\mathrm{b}} \\
\text { (Accepted) }\end{array}$ & $\begin{array}{c}\mathrm{H} 2_{\mathrm{c}} \\
\text { (Not } \\
\text { Accepted) }\end{array}$ & $\begin{array}{c}\mathrm{H} 2_{\mathrm{d}} \\
\text { (Not Accepted) }\end{array}$ \\
\hline \multirow[t]{2}{*}{$\mathrm{BCI}$} & $\begin{array}{c}\text { Highly } \\
\text { Significant } \\
\text { Negative }\end{array}$ & $\begin{array}{c}\text { Highly } \\
\text { Significant } \\
\text { Positive }\end{array}$ & $\begin{array}{l}\text { Significant } \\
\text { Positive }\end{array}$ & Insignificant & Insignificant \\
\hline & $\begin{array}{c}\mathrm{H} 1_{\mathrm{b}} \\
\text { (Accepted) }\end{array}$ & $\begin{array}{c}\mathrm{H} 3_{\mathrm{a}} \\
\text { (Accepted) }\end{array}$ & $\begin{array}{c}\mathrm{H} 3_{\mathrm{b}} \\
\text { (Accepted) }\end{array}$ & $\begin{array}{c}\mathrm{H} 3_{\mathrm{c}} \\
\text { (Accepted) }\end{array}$ & $\begin{array}{c}\mathrm{H} 3_{\mathrm{d}} \\
\text { (Not Accepted) }\end{array}$ \\
\hline \multirow[t]{2}{*}{ SRII } & $\begin{array}{c}\text { Highly } \\
\text { Significant } \\
\text { Negative }\end{array}$ & $\begin{array}{l}\text { Highly } \\
\text { Significant } \\
\text { Positive }\end{array}$ & $\begin{array}{l}\text { Significant } \\
\text { Positive }\end{array}$ & $\begin{array}{l}\text { Significant } \\
\text { Positive }\end{array}$ & Insignificant \\
\hline & & $\begin{array}{c}\mathrm{H} 4_{\mathrm{a}} \\
\text { (Accepted) }\end{array}$ & $\begin{array}{c}\mathrm{H} 4_{\mathrm{b}} \\
\text { (Accepted) }\end{array}$ & $\begin{array}{c}\mathrm{H} 4_{c} \\
\text { (Accepted) }\end{array}$ & $\begin{array}{c}\mathrm{H} 4_{\mathrm{d}} \\
\text { (Not Accepted) }\end{array}$ \\
\hline \multirow[t]{2}{*}{ EM } & & $\begin{array}{l}\text { Significant } \\
\text { Positive }\end{array}$ & $\begin{array}{l}\text { Significant } \\
\text { Positive }\end{array}$ & $\begin{array}{l}\text { Significant } \\
\text { Positive }\end{array}$ & Insignificant \\
\hline & & $\begin{array}{c}\mathrm{H} 5 \mathrm{a} \\
\text { (Accepted) }\end{array}$ & $\begin{array}{c}\mathrm{H} 5 \mathrm{~b} \\
\text { (Accepted) }\end{array}$ & $\begin{array}{c}\mathrm{H} 5_{c} \\
\text { (Accepted) }\end{array}$ & $\begin{array}{c}\mathrm{H} 5_{\mathrm{d}} \\
\text { (Not Accepted) }\end{array}$ \\
\hline \multirow[t]{2}{*}{$\begin{array}{l}\mathrm{BCI} \text { and EM } \\
\text { Moderation }\end{array}$} & & $\begin{array}{l}\text { Significant } \\
\text { Negative }\end{array}$ & $\begin{array}{l}\text { Significant } \\
\text { Negative }\end{array}$ & $\begin{array}{l}\text { Significant } \\
\text { Negative }\end{array}$ & Insignificant \\
\hline & & $\begin{array}{c}\mathrm{H} \mathrm{b}_{\mathrm{a}} \\
\text { (Accepted) }\end{array}$ & $\begin{array}{c}\mathrm{H} 6_{b} \\
\text { (Accepted) }\end{array}$ & $\begin{array}{c}\text { H6c } \\
\text { (Not } \\
\text { Accepted) }\end{array}$ & $\begin{array}{c}\mathrm{H} 6_{\mathrm{d}} \\
\text { (Not Accepted) }\end{array}$ \\
\hline $\begin{array}{l}\text { SRII and EM } \\
\text { Moderation }\end{array}$ & & $\begin{array}{l}\text { Significant } \\
\text { Positive }\end{array}$ & $\begin{array}{l}\text { Significant } \\
\text { Positive }\end{array}$ & Insignificant & Insignificant \\
\hline
\end{tabular}




\section{Conclusion}

This paper examines the role of board characteristics and shareholder's rights to information in containing earnings management practices and ultimately their impact on the financial performance on the listed commercial banking sector of Pakistan. The previous studies focused only on just loan loss provisions as a proxy to measure earnings management in banking sector in case of developing countries like Pakistan which deviates the facts as suggested by the Stubben (2010) to assess earnings management because of its omission of the non-discretionary part. This study incorporated just the discretionary part of the loan loss provisions using Stubben (2010)model to assess earnings management in the listed commercial banking sector of Pakistan.

The study also examines the relationship of two key internal governance indicators with earnings management and financial performance. The evidence is found that both board and shareholder's rights to information has a highly significant negative relationship with that of earnings management in banking companies when observed directly whereas shown only moderating significant negative impact of shareholders' rights to information on earnings management and insignificant moderating impact for the board composition and functioning. The $r-$ squared for most of the regressions is less because there are also many other internal and external governance indicators that explain the given phenomena.

Finally, the findings of the study concluded with the existence of positive association between both internal governance mechanisms and financial performance indicators when observed directly but when earnings management moderated the relationship then almost all financial performance variables showed negative association except Tobin's $Q$ which showed insignificant response. The study provides implications for the different stakeholders of the listed commercial banking sector and also suggested that the strong internal control mechanisms and the lesser extent of information asymmetry to prevent earnings management behavior. 


\section{References}

Abed, S., Al-Attar, A., \& Suwaidan, M. (2012). Corporate governance and earnings management: Jordanian evidence. International Business Research, 5(1), 216.

Ahmed, H. A., \& Ghazali, N. A. M. (2013). A longitudinal examination of intellectual capital disclosures and corporate governance attributes in Malaysia. Asian Review of Accounting.

Al-Rassas, A. H., \& Kamardin, H. (2015). Directors' independence, internal audit function, ownership concentration and earnings quality in Malaysia. Asian Social Science, 11(15), 244-256.

Ali, W., Ali, S., Khan, M. M., \& Ghulam, W. A. (2020). Financial satisfaction of street vendors in Azad Kashmir: Moderating role of Customer relationship management. 12(04), 5440-5461.

Ali, W., Ali, S., \& Mehmood, S. (2020). Effect of Risk Management Practices on Banks Performance Moderating Role of Managerial Expertise as a Competitive Edge. IBT Journal of Business Studies, 16(1).

Amran, N. A., Ishak, R., \& Manaf, K. A. (2016). The influence of real earnings on Malaysian corporate board structure. The Social Sciences, 11(30), 7258-7262.

Balanda, K. P., \& MacGillivray, H. L. (1988). Kurtosis: a critical review. The American Statistician, 42(2), 111-119.

Beasley, M. S. (1996). An empirical analysis of the relation between the board of director composition and financial statement fraud. Accounting review, 443-465.

Beneish, M. D. (1997). Detecting GAAP violation: Implications for assessing earnings management among firms with extreme financial performance. Journal of Accounting and Public policy, 16(3), 271-309.

Benkel, M., Mather, P., \& Ramsay, A. (2006). The association between corporate governance and earnings management: The role of independent directors. Corporate Ownership \& Control, 3(4), 65-75.

Bernard, V. L., \& Douglas, S. K. (1996). What motivates managers' choice of discretionary accruals? Journal of Accounting and Economics, 22(1-3), 313-325.

Bornhorst, F., \& Baum, C. (2001). Levinlin: Stata module to perform levin-lin-chu panel unit root test.

Brennan, N., \& McDermott, M. (2004). Alternative perspectives on independence of directors. Corporate Governance: An International Review, 12(3), 325-336.

Bulmer, M. G. (1979). Principles of statistics: Courier Corporation. 
Cornett, M. M., McNutt, J. J., \& Tehranian, H. (2009). Corporate governance and earnings management at large US bank holding companies. Journal of Corporate finance, 15(4), 412-430.

Dechow, Sloan, R. G., \& Sweeney, A. P. (1995). Detecting earnings management. Accounting review, 193-225.

Dechow, P., Ge, W., \& Schrand, C. (2010). Understanding earnings quality: A review of the proxies, their determinants and their consequences. Journal of Accounting and Economics, 50(2-3), 344-401.

Fama, E. F. (1980). Agency problems and the theory of the firm. Journal of political economy, 88(2), 288-307.

Fama, E. F., \& Jensen, M. (1983). Separation of ownership and control. Journal of Law and Economics, 26, 301-325.

Healy, P. M., \& Krishna, P. G. (2001). Information asymmetry, corporate disclosure, and the capital markets: A review of the empirical disclosure literature. Journal of Accounting and Economics, 31(1-3), 405-440.

Hsu, M., \& Wen, S. (2015). The influence of corporate governance in Chinese companies on discretionary accruals and real earnings management. Asian Economic and Financial Review, 5(3), 391-406.

Jensen, M. C. (1993). The modern industrial revolution, exit, and the failure of internal control systems. the Journal of Finance, 48(3), 831-880.

Jones, J. J. (1991). Earnings management during import relief investigations. Journal of accounting research, 29(2), 193-228.

Kang, S., \& Kim, Y. (2012). Effect of corporate governance on real activity-based earnings management: Evidence from Korea. Journal of Business Economics and Management, 13(1), 29-52.

Khanchel, I. (2007). Corporate governance: measurement and determinant analysis. Managerial Auditing Journal.

Khodadadi, V., Sohelia, K., \& Abbas, A. (2010). The effect of corporate governance structure on the extent of voluntary disclosure in Iran. Business Intelligence Journal, 3(2), 151-164.

Klein, A. (2002). Audit committee, board of director characteristics, and earnings management Journal of Accounting and Economics, 33, 375-400.

Lawal, A. I., Nwanji, T. I., Opeyemi, O. O., \& Adama, I. J. (2018). Can corporate governance mechanisms deter earnings management? Evidence from firms listed on the Nigerian Stock Exchange. Aestimatio: The IEB International Journal of Finance(17), 220-233. 
Liao, L., Lin, T. P., \& Zhang, Y. (2018). Corporate board and corporate social responsibility assurance: Evidence from China. Journal of Business Ethics, 150(1), 211-225.

Lipton, M., \& Lorsch, J. W. (1992). A modest proposal for improved corporate governance. The business lawyer, 59-77.

Morris, R. D. (1987). Signalling, agency theory and accounting policy choice. Accounting and business Research, 18(69), 47-56.

Obigbemi, I. F., Omolehinwa, E. O., Mukoro, D. O., Ben-Caleb, E., \& Olusanmi, O. (2016). Earnings management and board structure: evidence from Nigeria. Sage Open, 6(3), 2158244016667992.

Olayemi, B. B. (2013). The effectiveness of corporate governance on real earnings management in selected Malaysian companies. Universiti Utara Malaysia,

Peasnell, K. V., Pope, P. F., \& Young, S. (2005). Board monitoring and earnings management: do outside directors influence abnormal accruals? Journal of Business Finance \& Accounting, 32(7-8), 1311-1346.

Persons, O. S. (2006). The effects of fraud and lawsuit revelation on US executive turnover and compensation. Journal of Business Ethics, 64(4), 405-419.

Roe, M. J. (1991). A political theory of American corporate finance. Columbia Law Review, 91(1), 10-67.

Roychowdhury, S. (2006). Earnings management through real activities manipulation. Journal of Accounting and Economics, 42(3), 335-370.

Scott, W. R. (2015). Financial Accounting Theory. Scarborough, Ontario: Prentice Hall Canada Inc.

Shamsi, A. F., Bashir, R., \& Panhwar, I. A. (2013). Corporate governance in pakistan: An empirical study. Transnational Corporations Review, 5(3), 46-59.

Shayan-Nia, M., Sinnadurai, P., Mohd-Sanusi, Z., \& Hermawan, A. A. (2017). How efficient ownership structure monitors income manipulation? Evidence of real earnings management among Malaysian firms. Research in International Business and Finance, 41, 54-66.

Stephen, L., \& Scott, R. (2011). Credit markets and financial information. Review of Accounting Studies, 16(3), 487-500.

Stubben, S. R. (2010). Discretionary revenues as a measure of earnings management. The accounting review, 85(2), 695-717.

Uadiale, O. (2012). Earnings management and corporate governance in Nigeria. 
Vafeas, N. (2000). Board structure and the informativeness of earnings. Journal of Accounting and Public policy, 19(2), 139-160.

Williamson, O. E. (1981). On the nature of the firm: some recent developments. Zeitschrift für die gesamte Staatswissenschaft/Journal of Institutional and Theoretical Economics(H. 4), 675-680.

Xie, B., Davidson III, W. N., \& DaDalt, P. J. (2003). Earnings management and corporate governance: the role of the board and the audit committee. Journal of Corporate finance, 9(3), 295-316.

Yao, K., Tang, J., Li, F., \& Jiang, Y. (2015). Institutional environment, heterogeneity of institutional investors and real earnings management. Systems Engineering(5), 6.

Yermack, D. (1996). Higher market valuation of companies with a small board of directors. Journal of financial economics, 40(2), 185-211. 